\title{
IS THERE PEACE IN DISORDER?
}

DOI: 10.20542/2307-1494-2020-1-181-182

Think Peace: Essays for an Age of Disorder. Ed. by T. de Waal. - Washington D.C.: Carnegie Endowment for International Peace, 2019. 78 p.

As the world changes, so does humanity. In modern times, as the world becomes increasingly interconnected, the pressure of power and the pursuit of peace have come to the forefront of the global agenda. As humanity ages and the outcomes of past conflicts become lessons, it seems the global community is striving more and more for peace. The acquisition of peace is no doubt an admirable goal, although the definition and means of achieving peace may be controversial. This point is laid out in a collection of essays "Think Peace: Essays for an Age of Disorder" (2019).

In the introduction, the editor, Thomas De Waal, addresses the concept of the "word peace". Citing the use of the term "security" as a replacement for "peace" in the late twentieth and, thus far, in the twenty-first centuries, he suggests that the notion of "peace" has been tarnished. He also analyzes the emergence of the pursuit of peace during the early twentieth century, using the authors of the Versailles Treaty and Andrew Carnegie's efforts to establish peace pushing institutions as his prime examples. De Waal concludes by stating that strong, complex international bodies (which, he admits, do not currently exist) are needed if peace is to be achieved.

In the first chapter, entitled "The Peacemakers of 1919 A Century On", Jay Winter explores various aspects of the Versailles Treaty (June 1919), in order to explain its ultimate ineffectiveness. He claims that all key decision-making powers behind the treaty were influenced by self-interest. He then identifies time constraints as a first significant barrier to the effectiveness of the treaty, stating that "rushing into peace made as little sense as rushing into war, but that is precisely what happened" (p. 8). He points at the exclusion of the losers from the process as a vital flaw in establishing a treaty which effectively promoted peace. Winter seems to share the belief, held by James Shotwell, that "the knowledge of German experts would have helped make the peace treaty a common instrument for peace rather than a victor's fiat" (p. 9). The third "fatal flaw" Winter identifies in the drafting of the Versailles Treaty is the placement of all responsibility for the war on Germany, as "outlined in Article 231 of the treaty" (p. 9). The fourth and final flaw highlighted by Winter is the way the League of Nations was constructed. He finds inconsistency within the League's stance on state sovereignty and the League's practice of enforcing such an idea as "Article 10 of the Covenant of the League of Nations provided for international military assistance to be given to a state that is a victim of aggression" (p. 10). He concludes by highlighting four effects of the Versailles Treaty's failure that resonate even now, one hundred years later. The inclusion of these points serves to establish his argument that the treaty was an extraordinary failure that hampered the possibility of peace in the long term - a failure from which the world is still recovering.

The second chapter by Bernard Bot, entitled "The Call of Unorthodox Diplomacy", explains the increasing difficulty of diplomacy in a world where more and more conflicts are fought by non-state actors rather than states (p. 15). Bot identifies the trouble with establishing long term peace and suggests giving parties equal say in negotiations. He also identifies the problem of making peace more attractive than war, although he makes sure to mention that what can be considered peace varies from case to case (p. 19).

In the third chapter, "Peacemaking in an Era of New Wars", Mary Kaldor provides a conceptual distinction between "old" and "new" wars, which she compares and contrasts, emphasizing the difficulty of ending "new" wars. She characterizes "old" wars as "both 
interstate wars and classic civil wars between governments and rebels, where the rebels are organized, in effect, as a state in waiting", while "new" wars are "better described as a social condition or even as a mutual enterprise in which numerous armed groups gain more from violence itself than from winning" (p. 22). Whereas "old wars were an essential element of state-building", contemporary wars "disassemble the state" (p. 2223).

The fourth chapter, entitled "No War, No Peace: Healing the World's Violent Societies", is written by Rachel Klein and Robert Muggah. It deals with where the world is heading, in terms of patterns of violence, which, they note, is, overall, in decline. They point out that number of terrorist attacks per year has decreased since 2014 (p. 29). In addition, they also note that when analyzing terrorist attacks, the focus should be on the causes of terrorism and the types of attacks carried out rather than their frequency. The authors identify state repression as the lead cause of terrorism (p. 32). They also conclude that state collusion worsens organized crime which, in contrast to political violence, is on the rise.

In the fifth essay, "From Cyber Swords to Plowshares", George Perkovich and Wyatt Hoffman address the emerging unknown that is cyber security. They suggest that, although cyber attacks have not yet been too destructive, the threat is growing, and the current state of cyber security may not suffice to mitigate such a threat (p. 35). Concerning the future of cyber security, the authors point to the burden of cyber security currently being largely borne by the private sector. They refer to a "cyber grey-zone" as an obstacle to cyber cohesion, arguing that it prevents mutual understanding of what is tolerable in regards to cyber attacks (p. 38). Overall, the essay reflects how unstable the current cyber stage is on a global scale.

The sixth essay, entitled "Law of War or Peace Through Law?" and authored by Frédéric Mégret, is about the dynamics between justice and peace. The author poses the question of whether one limits the other (p. 43). In mentioning various attempts by the international community to establish institutions for justice, the author establishes that justice and peace are distinctly related. Historically, justice was used as an instrument to promote peace between states. However, as wars are increasingly fought between states and non-state actors, the concept of "justice" in modern times often becomes part of the agenda of intervention within states (p. 47).

In the seventh and final essay, entitled "On Peace and the Spaces Between the Words", Brendan McAllister addresses the question also raised in all the essays of this collection - the question of what peace is. In McAllister's view, influenced by his personal experience with the conflict in Northern Ireland, peace is more than just the absence of war. According to him, "peace is born in the midst of violence" (p. 53). His experience leads him to conclude that peace can have many different meanings, for different people and in different contexts, however, it is ultimately based on truth, wholeness, and mediation. At times, violence in fact sets the stage for allowing peace actors to nurture and grow peace (p. 57).

This collection of essays is a concise, but thought-provoking insight into what is to come and a guide to develop a better, more tolerable world. It looks into the past and the present to give invaluable advice for the future. The book serves those who seek to make sense out of disorder, laying out the lessons of the past and their implications for the future in just a few short essays. It acknowledges the reality of the modern era and the difficulties ahead, while providing hope for the years to come.

Dalton Ailey, ${ }^{*}$ University of Texas, Austin

\footnotetext{
* The book review was written by Dalton Ailey (USA) as part of his exchange program at MGIMO-University, Moscow. Рецензия Далтона Эйли (Университет Техаса в Остине, США) написана в рамках программы обмена в МГИМО-Университете, Москва.
} 